\title{
'A Great Insight into Antiquity': Jacob Bryant and Jeremiah Milles and the Authenticity of the Poems of Thomas Rowley
}

\author{
Bernd Roling
}

When in 1861 the Rostock scholar of German literature, ${ }^{1}$ Karl Bartsch, published a study of Albrecht von Halberstadt, only a few lines of his author's original text, a medieval translation of Ovid, were available to him. ${ }^{2}$ They had been included in the renaissance version of the text published in an early printed edition by Jörg Wickram in $1545 \cdot{ }^{3}$ Bartsch, however, wanted to offer not just the surviving lines but the whole of the medieval work, and so he decided to back-translate Wickram's entire text back into Middle High German. The result was a new medieval original, for which the label 'forgery' would certainly have been rejected by the editors. Yet what is astonishing is the ease with which new 'originals' could be created even in the mid-nineteenth century. The most famous 'new' medieval text of the eighteenth century was put into print by a very different scholar, Thomas Chatterton. In his day he was discussed and read with at least as much enthusiasm as an author who is far more familiar beyond Great Britain today, MacPherson's Ossian - and also suffered a similar fate.

Chatterton was the best known literary prodigy of his era, penning his first poetry at the age of eleven. The England of his day was gripped by enthusiasm for the first critical editions of Chaucer and Lydgate and was starting to take an interest in medieval literature and the Middle Ages in general, greeting all surviving relics of national history and culture with near-euphoric excitement,

1 The translations of this paper has been prepared by Orla Mulholland. For helpful discussions I'd like to thank Koen Ottenheyn, Stephan Hoppe and Dorothee Huff.

2 Bartsch K., Albrecht von Halberstadt und Ovid im Mittelalter (2 vols.) (Quedlinburg: 1861).

3 Wickram Jörg, P. Ovidii Nasonis, deß aller sinnreichsten Poeten Metamorphosis [...] Etwan durch den Wolgelerten M. Albrechten von Halberstat inn Reime weiß verteutscht / Jetz erstlich gebessert und mit Figuren der Fabeln gezirt / durch Georg Wickram zu Colmar. [...] Epimythium [...] Gerhardi Lorichii Hadamarii. (Mainz, Ivo Schöffer: 1545).

(C) BERND ROLING, 2019 | DOI:10.1163/9789004378216_027

This is an open access chapter distributed under the terms of the prevailing CC-BY-NC-ND License 
as exhibited not least by Chatterton's antagonist Horace Walpole. ${ }^{4}$ In this atmosphere Chatterton bestowed upon England her most important late medieval poet, Thomas Rowley. A thorough knowledge of the relevant historical research literature, the works of William Lambarde and William Dugdale, and the use of the Middle English dictionaries available at the time, from Franciscus Junius to John Kersey, had enabled the precocious genius to produce a whole corpus of apparently Middle English poetry, which he attributed to his alter ego, the cleric Thomas Rowley. The latter, according to the supposed tradition, was a man of the early fifteenth century from Bristol, Chatterton's own home town, which had in the recent centuries become rich in the cotton and slave trades but which was put in the shade culturally by the prestige of older English towns like Canterbury or York. Chatterton himself did not live to see the success of his Middle English poems, nor the huge debate that arose over their forgery, the so-called 'Rowley controversy'. When the young poet met no success in Bristol, he had set off for London, where he again tried his luck as a poet, satirist and journalist, but this time under his own name. In the capital he ran into ever more serious financial difficulties, and the omens, too, had come thick and fast - in the churchyard of St Pancras he tripped and fell directly into an open grave -, and Chatterton put an end to his life with arsenic in a London garret at the age of just seventeen. For the nineteenth century he became the prototype of the unhappy romantic destroyed by the ignorance of the world around him.

Briefly the history of the composition and diffusion of the pseudo-medieval poems that Chatterton fabricated under the name of his medieval cleric Rowley, should be mentioned, before turning to the real topic of this study. Rowley's poems found not only opponents, who had raised doubts about their authenticity right from the start, but also defenders, above all two of the greatest English antiquaries of the period, Jacob Bryant and Jeremiah Milles, both of whom passionately maintained the poems' authenticity. For both these men what was decisive in the question of whether Rowley was the real author was not philological arguments, arguments that today seem entirely self-evident; rather, it was historical realia that would confirm the authority of the medieval poet. It was a past represented as perfectly and as persuasive as possible by Rowley. In this, both men were acting as typical representatives of their antiquarian guild, whose expert knowledge would assert its prestige by this

4 For a good survey of the rise of medieval studies in 18th century England see the excellent study of Matthews D., The Making of Middle English, 1765-1910 (Minneapolis: 1999), there esp. 25-53, and see also on the 'construction' of a 'medieval world' in the 18th century idem, Medievalism. A Critical History (Cambridge: 2015) 165-181. 
exercise. The strategies of argument that they deployed to support this ultimately hopeless cause is what I wish to trace in what follows.

\section{Forging Poetry and Forging an English Past: The First Doubts on Rowley's Authenticity}

Already in 1768 Chatterton had begun to launch the first texts by Rowley into the local press in Bristol. ${ }^{5}$ Steadily more works were created, including above all a grand epic The Battle of Hastings, which treated the battle of the English and the Normans and a tragedy called Aella set during the English battles against the Danes. In addition there were smaller showpieces, such as the 'English Metamorphosis', set in early English history; three 'English Eclogues'; a 'Ballad of Charity'; and finally verses explicitly addressed to the English poet John Lydgate, supposed to be a contemporary of Rowley. ${ }^{6}$ The genesis of these poems and their initial dissemination has by now been studied thoroughly, for example in the works of Eduard Meyerstein, Paul Baines, and especially the recent book by Daniel Cook, which was used here to great profit; ${ }^{7}$ in German there is also a recent Chatterton biography by Jürgen Heizmann. ${ }^{8}$ So

5 As first printing of Rowley the "Account of the ceremonies observed at the opening of the old bridge", in: Felix Farley's Bristol Journal (1768), later quoted in Rowley Thomas, Poems, supposed to have been written in Bristol by Thomas Rowley and others, in the Fifteenth Century: the greatest part now first published from the most authentic copies, ed. by Thomas Tyrwhitt (London, Thomas Payne: 1777) VI.

6 Rowley, Poems (1777), there e.g. "The Battle of Hastings", 210-274, "The Tragedy of Aella", 76172, the "English Eclogues", 1-18, or the "Ballad of Charity", 203-209.

7 As still most valuable biography of Chatterton see Meyerstein E.W.H., A Life of Thomas Chatterton (London: 1930), there on the Rowley poems 156-249, and see in addition Cook D., Thomas Chatterton and Neglected Genius, 1760-1830 (London: 2013), passim, there esp. 35-128, Russett M., Fictions and Fakes. Forging Romantic Authenticity, 1760-1845 (Cambridge: 2006) 50-69, Baines P., The House of Forgery in Eighteenth-Century Britain (Aldershot: 1999) 151176, Lolla M.G., "'Truth Sacrificing to the Muses': The Rowley Controversy and the Genesis of the Romantic Chatterton", in: Groom N. (ed.), Thomas Chatterton and Romantic Culture (Basingstoke: 1999) 151-172, Giovanelli L., Falsi d'Autore. Percy, Macpherson, Chatterton (Pisa: 2001) 222-242, Taylor D.S., Thomas Chatterton's Art. Experiments in imagined History (Princeton: 1978) 44-78, and Grafton A., Forgers and Critics. Creativity and Duplicity in Western Scholarship (Princeton: 1990) 50-59.

8 Heizmann J., Chatterton oder Die Fälschung der Welt (Heidelberg: 2009), there on the Rowley poems 124-150, and see also Hoefer N., Chatterton oder der Mythos des ruinierten Poeten. Werk und Wirkung des englischen Dichters (Köln: 2010), there on Rowley 82-97. For a survey of the reception of Rowley's poems in Germany see Guthke K.S., "The Rowley Myth in EighteenthCentury Germany", Papers of the Bibliographical Society of America $5^{1}$ (1957) 238-241. 
far only Cook has given attention to the role of the antiquaries in the Rowley controversy. ${ }^{9}$

In Bristol, the city eulogised, which now finally had its own Shakespeare, Rowley's poems had been greeted with great enthusiasm. ${ }^{10}$ Local worthies with an interest in history, such as George Symes Catcott and William Barrett had taken an interest in the Rowley manuscripts which Chatterton, in contrast to MacPherson, had promptly made available. William Barrett incorporated the figure of Rowley into his current history of Bristol, thus finally discovering the hitherto lacking principal witness to the city's medieval history. ${ }^{11}$ Right from the start, as has been shown above all by Daniel Cook, the major journals of the period, above all the Gentleman's Magazine and the St James's Chronicle, had also followed the publications of Rowley's work with critical interest. ${ }^{12}$

Doubts about the authenticity of the poems and their credibility had arisen very early. Already when Thomas Tyrwhitt published the first edition of the Rowley poems in 1777, he voiced cautious scepticism but nonetheless printed Chatterton's manuscripts without commentary and almost unaltered, including the explanations of vocabulary and glosses that had been added by the supposed discoverer and transcriber of the manuscripts, namely Chatterton himself. ${ }^{13}$ Tyrwhitt had previously won attention as editor of Chaucer's Canterbury Tales and in so doing had shown himself to be a knowledgeable scholar. ${ }^{14}$ In the third printing of his edition Tyrwhitt added an appendix that directly linked the sensational discovery to the person of Chatterton as author. ${ }^{15}$ On the basis of the pseudo-medieval language alone, Tyrwhitt now stressed, the poems could not possibly derive directly from the Middle Ages. ${ }^{16}$ Serious doubts were then added by Thomas Warton, who from 1774, i.e. four years after

9 Cook, Thomas Chatterton 103-114.

10 For a colourful picture of Chatterton's Bristol see e.g. Barry J., "Chatterton, More and Bristol's Cultural Life in the 176os", in: Heys A. (ed.), From Gothic to Romantic: Thomas Chatterton's Bristol (Bristol: 2005) 20-35.

11 Barrett William, The history and antiquities of the city of Bristol, compiled from original records and authentic manuscripts, in public offices or private hands (Bristol, William Pine: 1789), there e.g. 637-639.

12 Cook, Thomas Chatterton 55-68.

13 Rowley, Poems (1777), there esp. XI-XII.

14 The Canterbury Tales of Chaucer, to which are added, an essay upon his language and versification; an introductory discourse; and notes, ed. Thomas Tyrwhitt (5 vols.) (London, Thomas Payne: $1775^{-1778)}$.

15 On Tyrwhitt's longtime interest in Rowley see already Powell L.F., "Thomas Tyrwhitt and the Rowley Poems", Review of English Studies 7 (1931) 314-326.

16 Poems, supposed to have been written in Bristol by Thomas Rowley and others, in the Fifteenth Century: the third edition, to which is added an appendix, containing some observations upon the language of these poems, tending to prove, that they were written, not 
Chatterton's death, had begun to write the first extensive history of English poetry and had included Rowley in his chapter on the Middle Ages. According to Warton, the poet, who had died so young, had written the poems himself as a bid for attention and had then published them under an invented identity; tragedies and epics of the kind Rowley had composed were not written in the early fifteenth century, so they were necessarily anachronistic. The poems of Rowley therefore retained their undoubted class, Warton insisted, indeed their genius, but there was no way they were a product of the fifteenth century. ${ }^{17}$

\section{The Antiquarian's Revenge: Hegemonical Knowledge as a Key to} the Past

\subsection{Representing the Middle Ages:Jacob Bryant's Defence of Rowley}

Then in 1782 centre-stage was taken by two men who could be considered historians and antiquaries, but not philologists, Jacob Bryant and Jeremiah Milles. Jacob Bryant, a fellow in Kings College, Cambridge, was one of the most important antiquaries of his time and at that point had a long career behind him as mythographer and antiquarian researcher. His massive New System, or an Analysis of Ancient Mythology had attempted over hundreds of pages to devise a general key to all mythologies, which in long chains of filiation aimed to trace all myths back to their Old Testament origins. Since the landing of the Ark, so ran Bryant's basic thesis, these elemental building blocks of all religions had been diffused among the nations and had been articulated in ever new adaptations of the same system. ${ }^{18}$ Bryant's key to mythology, bristling with erudition, had been so successful that he followed it up with a whole series of linked works, right through to his own lexica. ${ }^{19}$ Highly controversial, but no less well known, was Bryant's attempt to unmask all the traditions about Troy

by any ancient author, but entirely by Thomas Chatterton, ed. Thomas Tyrwhitt (London, Thomas Payne: 1778) 311-333.

17 Warton Thomas, The History of English Poetry from the close of the eleventh to the commencement of the eighteenth century (3 vols.) (London, James Dodsley: 1774-1781), vol. II, § 8, 139-164.

18 Bryant Jacob, A New System, or An Analysis of Ancient Mythology (3 vols.) (London, Thomas Payne: 1775-1776) (reprint New York: 1979), there on the basic concept vol. I, 1-3.

19 As parallel studies see Bryant Jacob: Observations and Inquiries relating to various parts of Ancient History (Cambridge, John Archdeacon: 1767), as lexicon of Bryant see Holwell William, A mythological, etymological and historical dictionary, extracted from the Analysis of Ancient Mythology (London, Charles Dilly: 1793). As critical response to Bryant's attempt see e.g. Richardson John, A Dissertation on the Languages, Literature, and Manners of Eastern Nations (Oxford, University Press: 1778), there Part II, c. 2, Section I-III, 318-412. 
as mere speculation for which no historical basis could be shown at all. ${ }^{20}$ Even his opponents had to acknowledge that hardly any antiquary could match the Cambridge don for erudition.

\subsubsection{Philological Approaches}

This overwhelming knowledge of historical detail by the antiquaries and their claim to have a superior right to pass judgement on the authenticity of Rowley's poems on the basis of this knowledge, rather than on the basis of any possible poetic criteria, moved Bryant to intervene in the debate, which by this time had really already been lost. ${ }^{21}$ Bryant's arguments in favour of the authenticity of the poems respond to the doubts of Tyrwhitt and Warton, but above all they aim for a historical authentification of Rowley's poems. The prestige of the antiquarians' discipline meant they had to make its weight felt. For Bryant, it had to be demonstrated that at the age of 15 the young Chatterton could not possibly have composed the poems of Rowley, with their comprehensive, subtle medieval background and their positioning in cultural history, something that ought to be accessible only to the expert. Indeed, so Bryant maintained, Chatterton himself as editor had not even properly understood the poems in all their complexity, unlike Bryant and his fellow scholars. As I will show, Bryant here adopted a somewhat different strategy to defend them from that of his colleague Milles.

Bryant's approach to the text was twofold: he attempted, at least superficially, to set Rowley's language in its historical context but also to address what was his own real main interest, namely the explanation of historical realia. As regards Rowley's English idiom, the 'dialect', as Bryant called it, Bryant believed he could identify the language of the poems as a dialect of late medieval Somerset, comparable to the many other local idioms that England had brought forth in its history. ${ }^{22}$ Rowley's language overflowed with Latinisms, as appropriate to the Ango-Norman origin of the work. Rowley wrote 'crine' instead of 'hair' or 'volande' instead of 'will', 'jintle' instead of 'gentle', like so many poets of the same provenience. Reference texts that could help set Rowley in his poetic context were Langland, Chaucer and of course Lydgate, who had all written at around the same time or a little earlier. In addition there was

20 Bryant Jacob, Observations upon a treatise, entitled a Description of the plain of Troy, by Monsieur le Chevalier (Eton, Maria Pote: 1795), and enlarged idem, A dissertation concerning the War of Troy, and the expedition of the Grecians, as described by Homer (London, n.p.: $1796[?])$.

21 Bryant Jacob, Observations upon the Poems of Thomas Rowley, in which the authenticity of those poems is ascertained (London, Thomas Payne: 1781). 
the Virgil translation of Gavin Douglas, of importance above all on account of its classical reminiscences. ${ }^{23}$ Special authority as a comparison, in Bryant's view, was held by the verse chronicle of Robert of Gloucester, which in content, too, was especially close to the historical poet Rowley. Like so many of the works of English historiography, it had been edited a few years previously by the great English antiquary Thomas Hearne and so was easily accessible. ${ }^{24}$

\subsubsection{Antiquarian Knowledge and Folklore}

That Bryant's hypotheses on the supposed medievalness of Rowley's language were built on sand needs no further demonstration. Of far greater interest for us are Bryant's attempts to demonstrate the additional historical value yielded by Rowley's poems. From a few simple phrases Bryant believed he could show that Chatterton had simply misunderstood his text. Rowley had selected the decidedly rare word 'goffyngely' to describe the rather pointless utterance of a character. Chatterton in his glossary had chosen the translation 'foolishly'. But in truth, so Bryant, the term stood for the 'meaningless' character of the words. The course of a certain river is described as 'bysmare', a phrase that Chatterton in the glossary to his own lines explained as 'curious'. Yet a glance at Bede would have shown that it rather corresponded to the Latin words sonorus and horrendus. ${ }^{25}$ 'Grange', another word of Rowley's, was translated by Chatterton in his footnotes, as in later English, as 'landed estate', but in the poem's original context it should really mean 'barn', for it was derived from the Latin granagrium, the 'grain store'. Chatterton had no Latin, but Rowley certainly did. ${ }^{26}$

Other historical details of the poems revealed a close knowledge of the everyday life of the late Middle Ages in England that, so Bryant maintained, would have been available only to a person who lived in this period or, as one may infer, to someone like Bryant who had studied this past so intensively as to have achieved the same arcane level of knowledge. One of the two outstanding

23 Douglas' translation of the Aeneid was prepared in the year 1513. For a more recent edition of his text see e.g. Douglas Gavin, The Aeneid, ed. by G. Kendal (2 vols.) (London: 2011). As basic authority on the Old English language for Bryant see Hickes Georges, Linguarum veterum septentrionalium thesaurus grammatico-criticus et archaeologicus (Antiquae litteraturae septentrionalis libri duo vol. I) (Oxford, University Press: 1705), vol. I, and idem, Grammatica Anglo-Saxonica, ex Hickesiano thesauro excerpta (Oxford, University Press: 1711).

24 Hearne Thomas, Robert of Gloucester's chronicle, to which is added, besides a glossary and other improvements, a continuation (by the author himself) of this chronicle from a ms. in the Cottonian Library (Oxford, University Press: 1724).

25 Bryant, Observations upon the Poems of Thomas Rowley 59-67.

26 Ibidem $35^{-38 .}$ 
pieces in Rowley's work-catalogue had been the Tragedy of Aella, a 'Tragical Interlude'. It had depicted the heroic struggle of the eponymous Warden of Bristol, governor of the town, who had been betrayed by his wife following an intrigue in the struggle against the Danes; the work was set in the eleventh century. It did not escape Bryant either that this text necessarily gave rise to doubts. ${ }^{27} \mathrm{~A}$ theatrical play composed in the late Middle Ages in the style of a classical tragedy treated a historical theme which, at the time the work was produced, was itself 300 years in the past? Were tragedies being written in England at all at this time? The medieval historians, William of Worcester and others, had reported bible dramas and morality plays on the English stages, but no tragedies. ${ }^{28}$ Yet, as Bryant knew, Lydgate had told his readers of 'tragedies and comedies' that he claimed to have written, so why should there not also have been dramatic stagings of tragedies? ${ }^{29}$

Rowley's title figure, the brave Briton Aella, could be confirmed from Old Norse literature: Ragnar Lodbrog had fought a battle against a hero of this name in the early eleventh century. In 1016 there had in fact been, just as Rowley claimed, a peace deal with payments of Danegeld between the English and the Danes, for Simeon of Durham had reported such an agreement. ${ }^{30}$ And the significance of Bristol in the high Middle Ages, from whose fortifications the hero of the drama had ridden out to battle against the Danes, could be traced to the relevant English historians, William of Malmesbury, Henry of Huntingdon and Florence of Worcester. ${ }^{31}$ Hence, Bryant stressed, the late medieval writer Rowley must have gained substantial knowledge of his home town's past, whereas the supposed creator of his poems, the youth Chatterton, could not have. ${ }^{32} \mathrm{~A}$ look at the detail was enough for Bryant to confirm that the author of the tragedy must have been a medieval author and not a person of the eighteenth century. ${ }^{33}$ The Danes, so it was said in Rowley, threw aside the 'Rafn', the 'raven', when they turned and fled at Bristol before the English troops. What had Rowley meant by that? Chatterton seemed not to have known, but Bryant

27 Ibidem 164-188.

28 William of Worcester, Itineraries, ed. J. Harvey (Oxford: 1969), there on Bristol 399-403.

29 Bale John, Scriptorum illustrium maioris Brytanniae, quam nunc Angliam et Scotiam vocant, Catalogus (Basel, Johannes Oporinus: 1557), Centuria VIII, Ioannes Lydgate, 587, and see Lydgate John, Troy Book, ed. Henry Bergen (4 vols.) (London 1906-1935), vol. II, Book II, v. 860-926, pp. 169-171.

Simeon of Durham, Historia regum, in: Opera omnia (2 vols.), ed. T. Arnold (London: $1882-$ 1885) (Reprint Nendeln: 1965), vol. II, § 128, 151-153.

31 As example see Henry of Huntingdon, Historia Anglorum, ed. D. Greenway (Oxford: 1996), Liber X, c. 7, 712-713.

32 Bryant, Observations upon the Poems of Thomas Rowley 198-204.

33 Ibidem 188-194. 
is able to extract some sense from the strange word and thus explain to the dead poet the meaning of his own poem. The raven was the sacred animal of Odin. The fact that it, like the wolf or the dragon, was depicted on the standards and flags of the Vikings was confirmed by both the Anglo-Saxon Chronicle and the Orkneyinga Saga ${ }^{34}$ So the Danes had simply dropped their standards when they turned their backs on England.

Yet Bryant had another trump up his sleeve and rises to real subtlety. In Rowley's second eclogue it was said of Richard the Lionheart, in a very laboured comparison, 'Kynge Rycharde, lyche a lyoncel of warre, / Inne sheenynge goulde, lyke feerie gronfers, dyghte'. ${ }^{35}$ But what were these 'feerie gronfers', in which the armour of the English king seemed to shimmer in an almost frightening way? Chatterton in his glossary had proposed a simple meaning: 'meteors', i.e. in this case 'ground fires' or those small will-o'-the-wisps that shimmer just above the topsoil, which were in Latin called ignisfatuus. ${ }^{36}$ Bryant was not satisfied with this statement by the supposed editor. ${ }^{37}$ Earthquakes might have led to large underground fires in England, which could perhaps be attributed escaping gas. Similar earthquakes with massive subterranean fires, i.e. 'groundfires', had been recorded in the Anglo-Saxon Chronicle for 1032 and by Simeon of Durham for Derbyshire in 1048, while other comparable reports were found in John Brompton, Raphael Holinshed and Roger of Hoveden, all reliable English chroniclers. ${ }^{38}$ These quakes with their 'groundfires' must have made a serious impression on the contemporary English populace. Why would they not also serve as a poetic point of reference for an author of the fifteenth century, in order to render his armoury of metaphors even more dazzling? Once again: Rowley had understood the subtle allusion, whereas Chatterton had not been able to decipher the poet's imagery in all its historical contours, for he had had no access to the world of the Middle Ages.

Other images, too, indicated the same thing for Bryant. Of an English female warrior to whom Rowley had given the beautiful name Kenewalcha, the poet had said in his epic on the Battle of Hastings that she was 'Majestic as

\footnotetext{
34 Thormod Torfaeus, Orcades seu rerum Orcadensium Historiae libri tres (Kopenhagen, Hög: 1697), Liber I, c. 10, 27.

35 Rowley, Poems (1777), Eclogue the second, 8-9.

36 Ibidem 9.

37 Bryant, Observations upon the Poems of Thomas Rowley 206-210.

38 As examples see Simeon of Durham, Historia regum $\S 137,164$, Anglo-Saxon Chronicle, trans. D. Whitelock (London: 1961), anno 1032, 102, and see also in the ancient edition available to Bryant Twysden Roger, Historiae anglicanae scriptores (London, Jacob Flesher: 1652), there Simeonis Dunelmensis Historia, col. 184, and Chronicon Johannis Bromton, col. 939 .
} 
Hibernies Holie Wood, / Where sainctes and soules departed masses synge.39 The chain of epithets would hardly make sense, Bryant explained, unless one knew that such holy woods had in fact existed in Ireland right into the mideleventh century, not least in the vicinity of Dearmach, where Saint Columba had once founded a monastery. ${ }^{40}$ The veneration of the leading Irish saint, Brigid, which, as Gerald of Wales had known, was linked to the cult of a holy fire, was also cited by Bryant in this connection. ${ }^{41}$ Rowley must have still had knowledge of these traditions. The bold Kennewalcha had attracted other similes, too, in Rowley's Hastings epic: 'As the blue Bruton, rysinge from the wave, / Like sea-gods seeme in most majestic guise, / And rounde aboute the risynge waters lave, / And their longe hayre arounde their bodie flies, / Such majestie was in her porte displaid, / To be excelld bie none but Homer's martial maid. ${ }^{42}$ The 'blue Bruton'? The ancient Picts had rubbed their entire bodies with blue paint, as Caesar had recorded in his Commentarii, and as had also been reported by Herodian and other ancient authors. If one credited these historiographers, the ancient Celts had also all gone swimming together. Where could a young man like Chatterton have acquired the antiquarian expertise needed to draw such an elegant and specific image of the perfect woman? ${ }^{43}$

Bryant was able to give many other examples of his own erudition, the results of which he painstakingly ascribed to Rowley and so to Chatterton. The extravagant pointed shoes, the 'shoon-pykes', that Rowley had imagined his figures wearing, seem to have been unknown in the fifteenth century, but Bryant finds evidence of them. ${ }^{44}$ The 'nyghte-mares' that haunt Aella are revealed as incubi, as they had been described in detail by medieval demonology. ${ }^{45} \mathrm{~A}$ princely magician called Tynan, recorded by Rowley at the Battle of Hastings,

39 Rowley, Poems (1777), Battle of Hastings, 259.

40 Bryant, Observations upon the Poems of Thomas Rowley 240-243.

41 Gerald of Wales, “Topographia hibernica”, in: Opera (9 vols.), ed. J.S. Brewer - J.F. Dimock (London: 1861-1891) (reprint Nendeln: 1964), vol. v, Distinctio II, c. 35-36, 121-122, and c. 48,131 , and as contemporary authority for Bryant see Ware Jacob, De Hibernia et Antiquitatibus eius, disquisitiones, in quibus praeter ea quae de Hibernia antiqua explicantur, mores et consuetudines Hibernorum, tam veterum quam mediorum temporum, describuntur (London, John Grismond: 1654), c. 4, Sectio I, 30-34, c. 17, Sectio 6, 96-97.

42 Rowley, Poems (1777), Battle of Hastings, 257.

43 Bryant, Observations upon the Poems of Thomas Rowley $263-266$.

44 Ibidem 292-294, see for laws against comparable shoes under the Reign of Edward the Fourth e.g. Stow John - Howes Edward, Annales, or A Generall Chronicle of England [...], continued and augmented with matters foraigne and domestique, ancient and moderne, unto the end of the present yeere 1631 (London, Richard Meighen: 1631), anno 1463, 417.

45 Bryant, Observations upon the Poems of Thomas Rowley, 290-291, see Rowley, Poems (1777), Ælla, 137 . 
could be given a fuller meaning by Bryant too. Matthew of Westminster and Geoffrey of Monmouth had called him Tenancius; he had been a legendary ruler of Cornwall, who had magically banished Caesar's ships. ${ }^{46}$ Had Rowley in the fifteenth century not perhaps also learned of this figure through oral history, through the songs of the bards or other traditions, and had therefore given him a place in his poem? Bryant certainly regards it as plausible. ${ }^{47}$ When King Harold before the English troops at the Battle of Hastings had declaimed 'Godde and Seyncte Cuthbert be the worde to daie', then, Bryant stresses, he had not only called upon the English national saint as patron in the war, but had also alluded to the vision that Alfred the Great had had before the decisive Battle of Assendure against the Danes. ${ }^{48}$ Here too Cuthbert had appeared to the ruler and promised him a great victory. Aelred of Rievaulx, Simeon of Durham and William of Malmesbury had referred to this scene, and the learned cleric Rowley had woven it into his poem. ${ }^{49}$

Bryant moves on to the core of his own antiquarian work and indirectly also to his universal mythology when he tries to authenticate a distinctive term in Rowley's poems. Rowley repeatedly cites as a comparison a particular English festival, the 'Hogtide Festival', or 'Hoke-day'. Among other things one reads, 'As mastie dogs, at Hoc-tyde set to fyghte', or 'Browne as the nappy ale at Hoc-tyde game..$^{50}$ What was this festival that appeared to have prompted such excessive practices? Older antiquaries such as William Lambarde or John Spelman had linked the festival to the massacre of the Danes for which King Ethelred the Unready had been responsible in 1002. However, the murder of the Danish overlords had occurred on November 13, according to Bryant, while 'Hokeday' was celebrated in May; none of the older historians, neither Florence of Worcester nor Aelred of Rievaulx, linked the massacre of the Danes, of such fatal consequences to the English, with a festival, and nor did Rowley; indeed, the rest of history gave little reason to do so. ${ }^{51}$ Evidently the late medieval scholar Rowley, in Bryant's fabulation, had still known the true content of the 'Hogtide' festival. It was even in his own time celebrated in various corners of

46 Geoffrey of Monmouth, Historia regum Britanniae - The first variant version, ed. N. Wright, Cambridge 1988, § 53, 46, and Flores Historiarum (3 vols.), ed. H.R. Luard (London: 189o), vol. I, 77 .

47 Bryant, Observations upon the Poems of Thomas Rowley, 285-287.

48 Rowley, Poems (1777), Battle of Hastings, 212.

49 Bryant, Observations upon the Poems of Thomas Rowley 213-216, see for example William of Malmesbury, Gesta regum Anglorum (2 vols.), ed. T.D. Hardy (London: 1840) (reprint Vaduz: 1964), vol. I, Liber II, 180-181.

5o Rowley, Poems (1777), Battle of Hastings, 226, 258.

$5^{1} \quad$ As an example see Florence of Worcester, Chronicon, ed. B. Thorpe (2 vols.) (London: 1848-1849) (reprint Vaduz: 1964), vol. II, 155-156. 
Oxfordshire. Its curious practices - women stopped men on the open road and demanded a toll to pass, the singing of obscene songs and other sexually connoted rituals - recalled the festival of Anna Perenna in ancient Rome, as it had once been described by Strabo or Ovid, and other celebrations of the pagan calendar that were held in spring in the temple of Aphrodite. ${ }^{52}$ The festival was thus of an entirely different nature than the event that supposedly gave rise to it, and was part of the primordial traditions that had once upon a time reached the British Isles along with the druids..$^{53}$

All these aspects of traditional medieval cosmic knowledge gave the lie, Bryant concluded, to the idea that the young whippersnapper Chatterton could have been responsible for the works of Rowley. No one four hundred years later could possess such an insight into the historical context that he would be able to incorporate such a collection of allusions into his poems. How callow, in contrast, Bryant continued, were the poems that Chatterton himself had produced, his 'African Eclogues' which had barely mastered the topography of Africa, or his treatises such as the 'Origin and Design of Sculpture' which are bursting with errors in the Greek terminology. Rowley would never have been guilty of such shortcomings. ${ }^{54}$

\subsection{Jeremiah Milles: Knowledge of the Classics and a Medieval Antiquity}

A second antiquary, Jeremiah Milles, who was Dean of Exeter and hold the position of the President of the Society of Antiquaries, took it upon himself in 1782 to demonstrate the authenticity of the Rowley poems. Milles, too, was a renowned medievalist, but his approach to Rowley's works was oriented rather towards literary scholarship. ${ }^{55}$ Instead of, like Bryant, commenting on select passages historically, he offered the English public a new edition of Rowley's works, which he furnished with an extensive commentary in the footnotes. Of importance to Milles, too, was the gulf that clearly had to exist between Rowley's erudition and Chatterton's own level of specialist expertise. The latter, so Milles stubbornly maintained, knew neither Greek nor Latin, whereas the poems of Rowley were so full of classical references that they could never

$5^{2}$ As an example see P. Ovidius Naso, Fastorum libri VI, ed. E.H. Alton (Leipzig: 1978), Liber III, V. 523-66o.

53 Bryant, Observations upon the Poems of Thomas Rowley 295-304.

54 Ibidem, 465-468, see Chatterton Thomas, Miscellanies in Prose and Verse (London, Fielding and Walker: 1778 ), Narva and Mored, $56-60$, and The Death of Nicou, 61-65, and ibidem, On the Origin, Nature and Design of Sculpture, 142-148.

55 As a publication of Milles see e.g. Milles Jeremiah, Inscriptionum Antiquarum Graecarum et Latinarum liber, accedit Numismatum Ptolemaeorum, Imperatorum, Augustarum, et Caesarum in Aegypto cusorum e Scriniis Britannicis catalogus ([London], n. p.: 1752). 
have been produced without a matching grounding in the classics. At another level, too, the contradiction was plain for all to see. Chatterton had been a slow learner, his first biographers had recorded, but Rowley must have possessed a magnificent store of learning. Rowley had been of deeply moral character, an earnest spirit of great righteousness, which was given voice in his poetry; Chatterton, to the contrary, had been a temperament full of feelings and sentiment, reckless and ultimately unstable, as his early death made clear, who was wholly lacking in the qualities needed to compose Rowley's sublime poetry. How dismal were the desperate letters, Milles insisted, that the young poet in his despair had sent to his mother from London, how trivial and vulgar his journalistic commissions, which seem to be governed only by the concerns of the day, when they are set alongside Rowley's poetry. Chatterton fell far short. ${ }^{56}$

An argument in favour of Rowley was his education and especially, Milles believed, his knowledge of Homer, which - despite the widely read English translation of Alexander Pope - Chatterton could never have acquired, apparently. Admittedly it was yet to be clarified how much Rowley could have read of Homer's text in the Middle Ages. Milles, too, knew that the Iliad and Odyssey had been known only indirectly in the fourteenth century, but the Troy Romances and Latin poems about Troy, such as those which Josephus Iscanus had presented in England, and not least the English adaptations by Chaucer and Lydgate, showed how familiar the English Middle Ages had been with this theme.${ }^{57}$ The whole of Rowley's Hastings poem, Milles insisted, must therefore be understood straightforwardly as an epic written in Homeric style. It is thus hardly surprising that Milles in his annotations manages to find page after page of allusions by Rowley to Homer and Virgil. Almost every battle scene and almost every martial detail depicted on the field of battle could be traced back to a classical model and reduced to its well-worn commonplaces. Rowley had

56 Milles Jeremiah, Poems, supposed to have been written at Bristol in the fifteenth century by Thomas Rowley, Priest, with a commentary, in which the antiquity of them is considered, and defended (London, Thomas Payne: 1782), Preliminary Dissertation, 1-23.

57 As examples see the contemporary edition Joseph of Exeter, Daretis Phrygii historicorum omnium primi de bello Troiano libri sex, latino carmine a Josepho Exoniensi elegantissime redditi (London, Thomas Helder: 1675), and on Chaucer see Tyrwhitt, The Canterbury Tales of Chaucer, but also the later editions of Ritson Joseph, Pieces of Ancient Poetry from authentic Manuscripts and old printed copies (London, Thomas Egerton: 1791), and later idem, Ancient English Metrical Romances (3 vols.) (London: 1802). Both Lydgate and Chaucer had already been printed by the Caxton Press. For an impressive and wide-ranging survey on Troy-poetry in medieval and early modern England see Keller W., Selves and Nations. The Troy Story from Sicily to England in the Middle Ages (Heidelberg: 2008) 321-594. 
created an epic that was just as strongly shaped by the classical spirit as were the other medieval reworkings of the matter of Troy. ${ }^{58}$

The same classical foundation, an aemulatio of antiquity, that was characteristic of Rowley's era could be demonstrated also for the other poems of the cleric from Bristol. Rowley's eclogues were the oldest bucolic poems in the English language and, though they were produced long before Dryden and Barclay, they breathed a similar Virgilian spirit, which here at last returned to the origins of pastoral. Men like Petrarch or Boccaccio had, to the contrary, used the eclogue at best as a vehicle for political points. ${ }^{59}$ Rowley's 'Tragical Interlude' on the fate of the heroic Aella followed the prescriptions of classical tragedy and, therefore, as Bryant had already seen, had to be regarded as the first of its kind in England. ${ }^{60}$ In its unity of action and the strictness with which the arc of the action tends towards the catastrophe it was committed to classical ideals and could not, as might otherwise seem obvious, have been inspired by Shakespeare's Hamlet or Macbeth. In its moralism, on the other hand, it still manifested the spirit of the medieval morality plays, such as had in fact long dominated the stages of England. Rowley, so Milles insisted, had thus written a work that still belonged to the Middle Ages but which at the same time had already managed to open the way to a new era. ${ }^{61}$

However, what should interest us primarily is how Milles succeeds in using antiquities as evidence for the authenticity of the poems. A scene from the Tragedy of Aella showed how the Danish king Magnus conducts a 'sword sacrifice', a ritual offering of his weapon of war before the battle. More naturally this rite would recall practices such as are found also in Shakespeare's Macbeth, yet, as Milles added, in Rowley they were presented in a far less distasteful form. Customs such as this were indeed attested for the Danes, as Milles' colleague Joseph Strutt had just demonstrated, in Asser of Cherbury, the biographer of Alfred the Great: ergo, it was authentic. ${ }^{62}$ The mourning ritual that one of the other characters in the 'Tragical Interlude', Birtha, had to complete after the death of Aella, namely the scattering of flowers on the grave and the

$5^{8}$ Milles, Poems, Preliminary Dissertation, $23^{-28}$, and see the Commentary, Battle of Hastings, 113-114, 122, 137.

59 Ibidem, Preliminary Dissertation, 29-30, and Commentary, The Eclogues, 389-390, 398-399.

6o For a good introduction into Rowley's/Chatterton's concept of tragedy see Taylor, Thomas Chatterton's Art, 114-142.

61 Milles, Poems, Commentary, The Tragedy of Ella, 159-164.

62 Ibidem, Commentary, The Tragedy of Ella, 227, and see Strutt Joseph, Porða Anzel-cýnnan, or, a compleat view of manners, customs, arms, habits, etc., of the inhabitants of England [...], with a short account of the Britons, during the government of the Romans (3 vols.) (London, John Thane: 1774-1776), vol. I, 81. 
conciliation of the spirits of the dead, had parallels in numerous comparable, equally well attested customs which the great antiquary John Brand had likewise collected for the late Middle Ages. From where could Chatterton have known all these things? ${ }^{63}$ A short poem by Rowley, 'The English Metamorphosis' had drawn on a subject whose source the enthusiastic antiquary had been able to locate in an episode from the opening chapters of the Historia regum Britanniae of Geoffrey of Monmouth, namely the death of the eldest son of the Brutus who, according to legend, had been the founder of Britain. His name was Locrine. How much detailed reading of the relevant literature would have been needed to adapt this material if the author had not himself lived in the Middle Ages? ${ }^{64}$

Milles managed to turn into the key witness for the authenticity of Rowley's poems a construction that was probably the best known of England's national monuments, Stonehenge. The Battle of Hastings included the following powerfully imagery about the warrior Herrewald: 'Herrewald, borne on Sarim's spreddyng plaine, / Where Thor's fam'd temple manie ages stoode; / Where Druids, auncient preests, dyd ryghtes ordaine, / And in the middle shed the victyms bloude; / Where auncient Bardie dyd their verses synge, / Of Caesar conquer'd, and his mighty hoste, / And how old Tynan, necromancing kynge, / Wreck'd all hys shyppyng on the Brittish coaste, / And made hym in his tatter'd barks to flie, / 'Till Tynan's dethe and opportunity. / To make it more renomed than before, / (I, tho a Saxon, yet the truthe will telle) / The Saxonnes steynd the place wyth Brittish gore, / Where nete but bloud of sacrifices felle. ${ }^{65}$ The figure of King Tynan mentioned here had been explained already by Bryant. But Milles steps up to offer a grander interpretation. Old Sarim was Stonehenge, the latter, however, had in reality been a temple of Thor, as Rowley had maintained. The Celts had worshipped this god as Taran or Taranus; his image had been a striking element in the history of northern European religion. Evidently Rowley had also known that the druids had honoured their gods at Stonehenge with sacred fires, which were lit above all in May. Similar rituals had been described by Celtophiles like William Borlase or John Toland; contemporary antiquaries like John Brand in his Popular Antiquities had been able to follow their traces in

63 Milles, Poems, Commentary, The Tragedy of Ella, 254, and see Brand John, Observations on Popular Antiquities, including the whole of Mr. Bourne's Antiquitates vulgares (Newcastle, Thomas Saint: 1777), c. 4, 39-41.

64 Milles, Poems, Commentary, The English Metamorphosis, 353-354, and see Geoffrey of Monmouth, Historia regum Britanniae, §§ 23-25, 17-20.

65 Rowley, Poems (1777), Battle of Hastings, 224. 
popular belief, Milles insists, far back into the Middle Ages. ${ }^{66}$ Rowley had been familiar with these traditions. ${ }^{67}$

But, Milles continues, the English cleric had recalled a second tradition in his lines. Was Stonehenge also a grave monument for the Britons who had fallen to the Saxons? Geoffrey had reported the legend that the great magician Merlin had once magicked the stones of the megalith complex from Ireland to England in order to erect a grave monument for King Arthur. In Henry of Huntingdon, too, a reliable historian, there was talk of such a use of Stonehenge as grave precinct. ${ }^{68}$ Although, Milles explained, there were now good grounds to raise doubts about this explanation, what was decisive was not the factual use made of the pagan sacred architecture, but that the oral tradition had arisen since the early Middle Ages and that Rowley had evidently known about it. How could the young Chatterton, the question once again arose, have managed in such a short time to acquire a knowledge of all these strands of tradition? How could someone who in his youth, during the period in which the poems were supposedly composed, had never been more than three miles from Bristol, according to Milles, how could he have gained this specialist knowledge? Rowley's poetry must thus have been composed in the late Middle Ages. They had been written by a clergyman who knew Latin, who had studied both the classics and the medieval chronicles, and who, on top of all that, was also familiar with the oral tradition of his time. ${ }^{69}$

There is indeed something tragic about the way so much effort was expended to confer medieval authority on a text that never had any. And it may have appeared to immediate contemporaries strange and also unjust that Bryant and Milles granted academic legitimacy to the work of an author who in his lifetime would surely have been very glad of recognition and, above all, some

66 Toland John, "Specimen of the Critical History of the Celtic Religion and Learning, containing an account of the Druids", The Miscellanous Works of John Toland (2 vols.) (London, John Whiston: 1747), here 67-69, Borlase William, Observations on the Antiquities, historical and monumental, of the County of Cornwall, consisting of several essays on the first inhabitants, druid-superstition, customs and remains of the most remote antiquity, in Britain, and the British Isles (Oxford, William Jackson: 1754), Book II, c. 1, 56-6o, and see Brand, Observations on Popular Antiquities, 271-281.

67 Milles, Poems, Commentary, Battle of Hastings, 70-76.

68 Henry of Huntingdon, Historia Anglorum, Epistula ad Warinum, c. 9, 580-581, and Geoffrey of Monmouth, Historia regum Britanniae, §§ 128-132, 122-127.

69 Milles, Poems, Commentary, Battle of Hastings, $76-78$. 
money. The arguments that Bryant and Milles presented in defence of Rowley, so overloaded with sources and charged with status-consciousness, would not be the last of their kind. In the same year as Milles the classical philologists Rayner Hickford and John Fell presented a similar treatise, ${ }^{70}$ a year later their colleague Thomas James Mathias published a follow-up work which gave his predecessors' arguments yet another airing. ${ }^{71}$

But in reality the battle was already done. Both Thomas Tyrwhitt and Thomas Warton, who had both identified Chatterton as the author of the poems right from the off, delivered a response to the antiquaries. ${ }^{72}$ In his reply to Bryant Tyrwhitt was no longer prepared to spend much more time on the supposed historical realia. Not only was Rowley a figure not documented historically in any way, the idiom of his poems was, as Tyrwhitt demonstrated one more time in detail, simply not medieval English. As had been said from the start, their lines were drummed up from a patchwork of elements that their author, certainly with great poetic talent, had pieced together out of dictionaries, above all from the current Middle English dictionary of John Kersey, from which Chatterton had also taken his apparently mistaken explanations. But a weightier consideration was a simple argument which, as Tyrwhitt as first editor stresses, ought really to have ended the debate before it began. The manuscripts that Chatterton had presented and which neither Bryant nor Milles had ever inspected, were glaring forgeries, which with the best will in the world had nothing whatsoever to do with the Middle Ages. And there had never been any other textual witnesses. ${ }^{73}$ Warton would further succeed in demonstrating that 'Rowley' had made thorough use of the works of Spenser, Dryden and Pope, which had evidently been of great help to the young Chatterton

$70 \quad$ Hickford Rayner - Fell John, Observations on the Poems attributed to Rowley, tending to prove that they were really written by him and other ancient authors, to which are added remarks on the appendix of the editor of Rowley's poems (London, Charles Bathhurst: [1782]).

71 Mathias Thomas James, An essay on the evidence, external and internal, relating to the poems attributed to Thomas Rowley (London, Thomas Becket: 1783). Also the Preface of the 1794 reedition of Rowley's poems was still commending Milles commentary, see Rowley Thomas, Poems, supposed to have been written at Bristol, by Thomas Rowley, and Others (Cambridge, Benjamin Flower: 1794) (Reprint Oxford: 1990), Preface, VI.

72 See also on Tyrwhitt's and Warton's responses to Bryant and Milles Cook, Thomas Chatterton, 122-124.

73 Tyrwhitt Thomas, $A$ vindication of the Appendix to the Poems, called Rowley's, in reply to the answers of the Dean of Exeter, Jacob Bryant, esquire, and a third anonymous writer, with some further observations upon those poems, and an examination of the evidence which has been produced in support of their authenticity (London, Thomas Payne: 1782), there on the manuscripts esp. 116-128. 
in the composition of his works. Rowley's, or Chatterton's, poems were thus troublingly modern. ${ }^{74}$ These, now definitive, demonstrations of the falsifications would be followed up by other authors, including Edmund Malone, who jumped on the same bandwagon one more time, ${ }^{75}$ and Percival Stockdale, who was able to pick apart Bryant and Milles in detail in his lectures in the 1780 s. $^{76}$ There was even an Irishman, William Mason, who wrote a satire on Milles, adding an 'Epistelle to Doctoure Mylles' in Rowley-English, ${ }^{77}$ and William Julius Mickle, who claimed satirically that he had found another comparable medieval poem, the 'The prophecy of Queen Emma.78

Why would Bryant and Milles not concede that a highly gifted young man could have read the same secondary literary as themselves, such as, for example, the works of Joseph Strutt or William Borlase? From the desire to secure to an academic elite the authority to interpret its objects of study? Or from the same systematic blindness that a few decades previously had led a great philologist like Richard Bentley to 'improve' the works of Milton, because Milton himself, so Bentley believed, had not fully understood his own poetry? Both scholars, Bryant and Milles, thought themselves to be the only erudite interpreters of a past they had constructed by their own antiquarian knowledge, a past, perfectly fitting not only to a city like Bristol, neglected for such a long time, but also representing their own view of English medievalism. Bryant and Milles show above all that the apparatus of scholarship, in which the force of professorial hybris was prepared to grant only to oneself a right to access sources, instead of regarding them as being in the public domain, must almost

74 Warton Thomas, An enquiry into the authenticity of the poems attributed to Thomas Rowley, in which the arguments of the Dean of Exeter, and Mr. Bryant, are examined (London, James Dodsley: 1782), there esp. on the style of Rowley 9-33.

75 Malone Edmond, Cursory observations on the poems attributed to Thomas Rowley, a priest of the fifteenth century, with some remarks on the commentaries on those poems, by the Rev. Dr. Jeremiah Milles, Dean of Exeter, and Jacob Bryant, Esq., and a salutary proposal addressed to the friends of those gentlemen (London, John Nichols: 1782).

76 Stockdale Percival, Lectures on the truly eminent English Poets (2 vols.) (London: 1807), there extensively on Chatterton vol. II, 145-537. And see in addition for a summary on the debate also Gregory George, The Life of Thomas Chatterton, with criticism on his genius and writings, and a concise view of the controversy concerning Rowley's poems (London, George Kearsley: 1789) 174-226.

77 Mason William, An archaeological epistle to the Reverend and Worshipful Jeremiah Milles, D. D. dean of Exeter, president of the Society of antiquaries, and editor of a superb editions of the poems of Thomas Rowley, priest (London, John Nichols: 1782) 16-21.

${ }_{7} 8$ Mickle William Julius, The prophecy of Queen Emma, an ancient ballad lately discovered, written by Johannes Turgotus, Prior of Durham, in the Reign of William Rufus, to which is added by the editor, an account of the discovery and hints towards a vindication of the authenticity of the Poems of Ossian and Rowley (London, John Bew: 1782) 15-40. 
inevitably end up looking ridiculous. Intelligence, they should have learned, is also found outside universities.

\section{Bibliography}

Baines P., The House of Forgery in Eighteenth-Century Britain (Aldershot: 1999).

Bryant Jacob, Observations upon the Poems of Thomas Rowley, in which the authenticity of those poems is ascertained (London, Thomas Payne: 1781).

Cook D., Thomas Chatterton and Neglected Genius, 1760-1830 (London: 2013).

Giovanelli L., Falsi d'Autore. Percy, Macpherson, Chatterton (Pisa: 2001).

Grafton A., Forgers and Critics. Creativity and Duplicity in Western Scholarship (Princeton: 1990).

Heizmann J., Chatterton oder Die Fälschung der Welt (Heidelberg: 2009).

Hoefer N., Chatterton oder der Mythos des ruinierten Poeten. Werk und Wirkung des englischen Dichters (Köln: 2010).

Keller W., Selves and Nations. The Troy Story from Sicily to England in the Middle Ages (Heidelberg: 2008).

Matthews D., The Making of Middle English, 1765-1910 (Minneapolis: 1999).

Idem, Medievalism. A Critical History (Cambridge: 2015).

Meyerstein E.W.H., A Life of Thomas Chatterton (London: 1930).

Milles Jeremiah, Poems, supposed to have been written at Bristol in the fifteenth century by Thomas Rowley, Priest, with a commentary, in which the antiquity of them is considered and defended (London, Thomas Payne: 1782).

Rowley Thomas, Poems, supposed to have been written in Bristol by Thomas Rowley and others, in the Fifteenth Century: the greatest part now first published from the most authentic copies, ed. by Thomas Tyrwhitt (London, Thomas Payne: 1777).

Idem, Poems, supposed to have been written in Bristol by Thomas Rowley and others, in the Fifteenth Century: the third edition, to which is added an appendix, containing some observations upon the language of these poems, tending to prove, that they were written, not by any ancient author, but entirely by Thomas Chatterton, ed. Thomas Tyrwhitt (London, Thomas Payne: 1778) Russett M., Fictions and Fakes. Forging Romantic Authenticity, $1760-1845$ (Cambridge: 2006).

Taylor D.S., Thomas Chatterton's Art. Experiments in imagined History (Princeton: 1978).

Warton Thomas, The History of English Poetry from the close of the eleventh to the commencement of the eighteenth century (3 vols.) (London, Dodsley: 1774-1781). 